\title{
Calcium hydroxide influence in autogenous self- healing of cement-based materials in various environmental conditions
}

\author{
Influência do hidróxido de cálcio na autocicatrização \\ autógena de materiais a base de cimento expostos a \\ dferentes ambientes de exposição
}

1Deividi Maurente Gomes da Silva ${ }^{1}$ Universidade Federal do Rio Grande do

Porto Alegre - RS - Brasil

${ }^{2}$ Vanessa Giaretton Cappellesso 2Universidade Federal do Rio Grande do

Porto Alegre - RS - Brasil

${ }^{3}$ Maurício Germano Lopes Garcia ${ }^{3}$ Universidade Federal do Rio Grande do

Porto Alegre - RS - Brasil

${ }^{4}$ Angela Borges Masuero ${ }^{4}$ Universidade Federal do Rio Grande do

Porto Alegre - RS - Brasil

${ }^{5}$ Denise Carpena Coitinho Dal

Molin

${ }^{5}$ Universidade Federal do Rio Grande do

Porto Alegre - RS - Brasil

Recebido em 28/07/20

Aceito em 17/12/20

\section{Deividi Maurente Gomes da Silva \\ Vanessa Giaretton Cappellesso \\ Maurício Germano Lopes Garcia \\ Angela Borges Masuero \\ Denise Carpena Coitinho Dal Molin}

\begin{abstract}
everal factors, such as chemical shrinkage or environmental attack can

produce concrete cracks. Calcium hydroxide content from the environment

1 or cement hydration can promote the self-healing phenomenon (SHP). This

study evaluates the calcium hydroxide concentration influence on the self-

healing phenomenon of cement-based materials. Cracked mortars with different

types of cement, such as a filler, pozzolanic, and high initial strength, were

exposed to four environmental conditions. Titration was the method proposed to

determine the amount of calcium hydroxide content leached in the water, and the cracks closure were analyzed by optical microscopy. CPII F (Portland Cement, type II, compound with limestone) samples showed no trend to $\mathrm{Ca}(\mathrm{OH})_{2}$ leached, and to superficial cracking closure. Regarding CPV (Portland cement, type V, high initial strength cement) samples, their behavior showed the highest $\mathrm{Ca}(\mathrm{OH})_{2}$ content to all environmental exposure, and cracking closure to samples in submerged condition. Thus, a significant influence in the cracks' closure regarding the presence of $\mathrm{Ca}^{2+}$ leached to the exposure environments, and a water source related to this behavior seems to be a primary factor to improve the SHP.
\end{abstract}

Keywords: Calcium hydroxide content. Self-healing. Cracks. Environmental conditions.

\section{Resumo}

Diversos fatores, como retração química ou ataques ambientais podem produzir fissuras no concreto. $O$ teor de hidróxido de cálcio do meio ambiente ou a hidratação do cimento podem promover o fenômeno de autocicatrização (SHP). Este estudo avalia a influência da concentração de hidróxido de cálcio no fenômeno de autoicatrização de materiais à base de cimento. Argamassas fissuradas com diferentes tipos de cimento, com filler calcário, pozolânico e alta resistência inicial, foram expostas a quatro condições ambientais. A titulação foi o método proposto para determinar a quantidade de hidróxido de cálcio lixiviado na água, e fechamento das fissuras foi analisado por microscopia óptica. As amostras contendo CPII F não apresentaram tendência à lixiviação de $\mathrm{Ca}(\mathrm{OH})_{2}$ e à colmatação das fissuras. Quanto às amostras com $\mathrm{CPV}$, foi constatado o maior teor de $\mathrm{Ca}(\mathrm{OH})_{2}$ lixiviado para todas as exposições ambientais, e um acentuado fechamento das fissuras nas amostras submersas. Dessa forma, constata-se uma influência significativa no SHP frente à uma fonte de umidade e ao conteúdo de $\mathrm{Ca}^{2+}$ nos ambientes de exposição

Palavras-chave: Conteúdo de hidróxido de cálcio. Autocicatrização. Ambientes de exposição. 


\section{Introduction}

External loading, exposure environment, cement chemical reactions are common sources of cracks in cement-based matrices. Cracks allow the action of deleterious substances in cement-based matrices to intensify and corrode the steel rebars in reinforced concrete structures (ERSAN et al., 2015). Among the main consequences are the service life decrease of buildings and the precocious maintenance activities (VAN TITTELBOOM; DE BELIE, 2013; FERRARA et al., 2018).

Crack repairs may occur through different approaches:

(a) external actions, such as surface treatments, which consist of filling the crack and repair of other existing damage (LI et al., 2019; SÁNCHEZ et al., 2018); and

(b) through repairing itself by materials inserted into the matrix (ARAÚJO et al., 2018; BORG et al., 2018; ERŞAN et al., 2018; VAN BELLEGHEM et al., 2018; SELVARAJOO et al., 2020), either by the further cement anhydrous grains hydration and carbonation of Portlandite, a product of these hydration reactions (ANGLANI; TULLIANI; ANTONACI, 2020; MOSTAVI et al., 2015).

Self-healing phenomenon is affected, as described by Reinhardt et al., (2013) by physical factors, such as particles swelling, chemicals and mechanical, for example from the deposition of small particles in the cracks from the matrix itself or impurities present in the water from the exposure environment.

The matrix design is strongly associated with the autogenous self-healing mechanism. The cement type with or without mineral admixtures may increase the cracks closure even for those at mature ages. Chen and Ye (2019) evidenced that the complexity in understanding the phenomenon is associated with the multidisciplinary areas, including the mechanisms of binder dissolution, ion transport, and hydrates and carbonates formation. Specifically, regarding the calcium ions' transport, Huang et al. (2016) asserted that the crack region with the highest ionic concentration is responsible for the deposition of calcium carbonate, crystalline material with shallow solubility water, and largely responsible for autogenous self-healing.

Different exposure environment and crack widths are, for Suleiman and Nehdi (2018), a gap in the knowledge that needs more comprehension. Although significant advances in the chemical understanding of the self-healing phenomenon are available, the exposure conditions' influence requires more knowledge approaches. The study evaluated the influence of a calcium source on the self-healing phenomenon for mortars produced with three different cement types under four different environmental conditions.

\section{Theoretical background}

An approach to the self-healing of cement-based materials figures a worldwide interest in the building construction industry. The first intentional evaluation of the self-healing phenomenon, developed at the University of Illinois, was to evaluate the self-healing of composite materials in a polymeric matrix (DRY, 1996). In Brazil, one of the first records addressing this issue was made by Vieira (2008) when evaluating the mechanical recovery of concrete produced with different cement types, cracked at an early age.

Given several approaches and academic interests, the SHC 221 (Self-Healing Phenomena in Cement-Based Materials) technical committee was created by RILEM, as the aim to create standardized nomenclatures and clarify the discoveries concerning the phenomenon. Thus, Schlangen, Joseph e De Rooij (2013) divided the self-healing in cement-based materials into three groups: autogenic, autonomous, and repair. Therefore, the further anhydrous cement grains' hydration and the calcium hydroxide carbonation are the main mechanisms for its development. In the autonomous self-healing, different methodologies can promote the cracks healing or sealing, such as: crystalline admixtures (ARNDT, 2019; BORG et al., 2018; CUENCA; TEJEDOR; FERRARA, 2018; ROIG-FLORES et al., 2015), superabsorbent polymers (SILVA, 2018; SNOECK; PEL; DE BELIE, 2020), microorganisms (DA SILVA et al., 2015; ERŞAN et al., 2018; GONZÁLEZ et al., 2020), vascular networks (MINNEBO et al., 2017; SELVARAJOO et al., 2020), and fibers (BULLER et al., 2019; FERRARA; KRELANI; MORETTI, 2016; NISHIWAKI et al., 2012; ZHANG; QIAN; MA, 2014). Lastly, the repair is called the external action produced in the finished matrix to promote the crack healing, for example, crystalline admixture as a surface treatment (CAPPELLESSO, 2016), and microorganism compounds (DE MUYNCK; DE BELIE; VERSTRAETE, 2009). Therefore, each self-healing methodology has specific factors that influence its behavior with variations in the activation mechanisms and environmental conditions. 


\section{Materials, crack age and $\mathrm{Ca}^{2+}$ content on the self-healing behavior}

Autogenous self-healing may be affected by different factors to which the cement matrix is exposed, either by the materials used in its production, such as different cement and mineral admixtures or by the exposure environment or by the damage amount produced through mechanical stresses.

\section{Cement types and mineral admixtures}

The cement composition's primary materials are: clinker, supplementary cementitious materials (SCM), such as fly ash and blast furnace slag, and limestone filler. The NBR 16697 (ABNT, 2018) classifies the Brazilian types of cement, based mainly on mineral admixtures or special properties, like high initial strength.

Silicates present in clinker $\left(\mathrm{C}_{3} \mathrm{~S}\right.$ e $\left.\mathrm{C}_{2} \mathrm{~S}\right)$ have two main hydration products, the calcium silicate hydrates $(\mathrm{C}$ $\mathrm{S}-\mathrm{H})$ and the calcium hydroxide $(\mathrm{CH})$, also called Portlandite. Equations 1 and 2 express the chemical reaction of silicates' hydration obtaining the saturation limit of $\mathrm{CH}$ (DOUBLE; HELLAWELL; PERRY, 1978).

$\mathrm{C}_{3} \mathrm{~S}+5,3 \mathrm{H} \rightarrow \mathrm{C}_{1,7} \mathrm{SH}_{5}+1,3 \mathrm{CH}$

Eq. 1

$\mathrm{C}_{3} \mathrm{~S}+5,3 \mathrm{H} \rightarrow \mathrm{C}_{1,7} \mathrm{SH}_{5}+1,3 \mathrm{CH}$

Eq. 2

Where:

$\mathrm{C}=\mathrm{CaO}$;

$\mathrm{S}=\mathrm{SiO}_{2}$; and

$\mathrm{H}=\mathrm{H}_{2} \mathrm{O}$.

Calcite or calcium carbonate $\left(\mathrm{CaCO}_{3}\right)$ comes from, among other sources, the carbonation of calcium hydroxide $\left(\mathrm{CH}, \mathrm{Ca}(\mathrm{OH})_{2}\right)$ available as a hydration product in the cement matrix. Pozzolanic reactions can also consume the Portlandite, produce C-S-H, and turn the matrix denser (MEHTA; MONTEIRO, 2014). Thus, the self-healing phenomenon is directly associated with the $\mathrm{CH}$ content from the cement hydration (DE NARDI et al., 2017; HUANG; YE; PEL, 2016).

\section{Cracking age and crack width}

The autogenous self-healing mechanism depends on the cracking age. Considering the different stages in the binder hydration over time, at an early age the anhydrous cement particles hydrationare predominant, and the presence of an available moisture source is essential (VAN TITTELBOOM; DE BELIE, 2013; YANG; YANG; LI, 2011). On the other hand, when cracks occur at mature ages, the leaching of calcium hydroxide from the matrix carbonation becomes the primary self-healing mechanism. Huang et al. (2016) observed that autogenous self-healing occurs through different mechanisms with distinct development times. The anhydrous cement hydration occurs rapidly only in the presence of a moisture source; however, calcium hydroxide carbonation is a slow process.

Crack closures are also related to the width and geometry of the cracks (VAN MULLEM et al., 2019). Maes, Snoeck and De Belie (2016) and Suleiman and Nehdi (2018) reported that cement matrices produced with fly ash cement, in a submerged environment, presented cracks closure up to $300 \mu \mathrm{m}$. However, Snoeck et al. (2014) related no healed cracks larger than $150 \mu \mathrm{m}$ when working with similar materials but exposed to different environmental conditions. Additionally, the self-healing phenomenon is influenced not only by the materials' properties and exposure environments but also by the sample treatment and sample evaluation during their follow-up. Images obtained by optical microscopy, under analysis by the research group, suggest that the positioning of the specimen in its exposure environment may favor the self-healing phenomenon. For example, cracks with the largest width stored to the lower part of the exposure environment can seal slower than cracks with the largest width facing up.

\section{Exposure conditions and $\mathrm{Ca}(\mathrm{OH})_{2}$ leached}

Self-healing in cement-based materials should occur in a wet environment, with a high relative humidity, such as wetting and drying cycles, or in submerged conditions (FERRARA; KRELANI; CARSANA, 2014; SISOMPHON; COPUROGLU; KOENDERS, 2013; VAN TITTELBOOM; DE BELIE, 2013). Suleiman and Nehdi (2018) evaluated the phenomenon in mortars under two environmental conditions, submerged and wet-dry cycles with variable temperature $\left(-10,20\right.$ and $\left.40{ }^{\circ} \mathrm{C}\right)$, and relative humidity $(20,60$ and $90 \%)$. 
They concluded that although samples in wet-dry cycles did not present self-healing products, cracks with up to $300 \mu \mathrm{m}$ closed under submerged conditions.

Likewise, calcium content, leached from the matrix or an external source, may contribute to the crack closure. Huang e Ye (2015) noticed that cement matrixes exposed to an external calcium source in their curing environment showed a more significant permeability reduction than those cured in distilled water. Edvardsen (1999) stated that the calcium ions $\left(\mathrm{Ca}^{2+}\right)$ react with $\mathrm{CO}_{3}^{2-}$ íons and $\mathrm{HCO}_{3}^{-}$íons to produce calcite $\left(\mathrm{CaCO}_{3}\right)$, the reaction is influenced by the water $\mathrm{pH}$, as presented in Equations 3, 4 and 5. Thus, $\mathrm{CO}_{3}^{2-}$ íons concentration may be heterogeneous, as noted by Sisomphon, Copuroglu and Koenders (2013) when they state that the ions' concentration near the crack mouth is higher than inside the cracks, producing in this region a more significant formation of $\mathrm{CaCO}_{3}$ and, consequently, producing not uniform healing in the deep crack.

$$
\begin{aligned}
& \mathrm{H}_{2} \mathrm{O}+\mathrm{CO}_{2} \leftrightarrow \mathrm{H}_{2} \mathrm{CO}_{3} \leftrightarrow \mathrm{H}^{+}+\mathrm{HCO}_{3}^{-} \leftrightarrow 2 \mathrm{H}^{+}+\mathrm{CO}_{3}^{2-} \\
& \mathrm{Ca}^{2+}+\mathrm{CO}_{3}^{2-} \leftrightarrow \mathrm{CaCO}_{3}[\mathrm{pHwater}>8] \\
& \mathrm{Ca}^{2+}+\mathrm{HCO}_{3}^{2-} \leftrightarrow \mathrm{CaCO}_{3}+\mathrm{H}^{+}\left[7,5<\mathrm{pH}_{\text {water }}<8\right]
\end{aligned}
$$$$
\text { Eq. } 3
$$$$
\text { Eq. } 4
$$

\section{Materials and methods}

\section{Materials and mix design}

Mortars with quartz sand and different cement types are materials used in this study. Regarding the cements used, Portland Cement, type II, with limestone (CPII F 40), equivalent to Type II by C150/C150M (AMERICAN..., 2019) and CEM II/A-L by EN 197-1, Portland cement, type IV, pozzolanic (CPIV 32), comparable to type IP by C595/C595M (AMERICAN..., 2018) and CEM IV/B by EN 197-1 and Portland Cement, type V, high initial strength (CPV) as Type III by C150/C150M (AMERICAN..., 2019) and CEM 1 40R by EN 197-1, according to NBR 16697 (ABNT, 2018). The chemical, physical and mechanical properties are in Table 1.

Sulfur in the binder may be associated with its raw materials (limestone) or with the fuel (fuel oil, petroleum coke, or coal) used in its production (PECCHIO, 2013). The $\mathrm{SO}_{3}$ content may affect the mortars' setting time, and in the properties' description, shown in Table 1, CPII F and CPV cement types are out of Brazilian standard bounds. Compressive strength was performed in four specimens for each age (3, 7 and 28 days) and

\begin{tabular}{|c|c|c|c|c|c|c|c|}
\hline \multirow{2}{*}{\multicolumn{2}{|c|}{ Chemical composition }} & \multicolumn{6}{|c|}{ Content (\% mass) } \\
\hline & & CPII F & $\mathbf{L N}$ & CPIV & $\mathbf{L N}$ & CPV & $\mathbf{L N}$ \\
\hline \multicolumn{2}{|c|}{ Silicon Dioxide $\left(\mathrm{SiO}_{2}\right)$} & 12.78 & & 28.02 & & 12.80 & 4.50 \\
\hline \multicolumn{2}{|c|}{ Aluminum Oxide $\left(\mathrm{Al}_{2} \mathrm{O}_{3}\right)$} & 3.77 & & 14.29 & & 3.73 & \\
\hline \multicolumn{2}{|c|}{ Iron Oxide $\left(\mathrm{Fe}_{2} \mathrm{O}_{3}\right)$} & 4.13 & & 4.09 & & 4.89 & \\
\hline \multicolumn{2}{|c|}{ Calcium Oxide $(\mathrm{CaO})$} & 66.48 & & 41.45 & & 68.85 & \\
\hline \multicolumn{2}{|c|}{ Magnesium Oxide $(\mathrm{MgO})$} & 1.46 & & 0.88 & & 1.06 & $\leq 6.50$ \\
\hline \multicolumn{2}{|c|}{ Sulphur Trioxide $\left(\mathrm{SO}_{3}\right)$} & 6.84 & $\leq 4,00$ & 4.06 & $\leq 4.50$ & 4.69 & $\leq 4.50$ \\
\hline \multicolumn{2}{|c|}{ Potassium Oxide $\left(\mathrm{K}_{2} \mathrm{O}\right)$} & 1.19 & & 1.84 & & 1.47 & \\
\hline \multicolumn{2}{|c|}{ Carbon Anhydride $\left(\mathrm{CO}_{2}\right)$} & 2.93 & $\leq 5,00$ & 3.83 & $\leq 5.50$ & 1.36 & $\leq 3.00$ \\
\hline \multicolumn{2}{|c|}{ Loss of Ignition (LOI) } & 5.20 & $\leq 6,50$ & 4.23 & $\leq 6.50$ & 3.09 & $\leq 4.50$ \\
\hline \multirow{3}{*}{$\begin{array}{l}\text { Laser } \\
\text { Granulometr } \\
\mathrm{y}(\mu \mathrm{m})\end{array}$} & Average diameter & 12.84 & & 10.07 & & 11.35 & \\
\hline & Diameter $10 \%\left(\mathrm{D}_{10}\right)$ & 0.34 & & 0.50 & & 0.31 & \\
\hline & Diameter $90 \%\left(\mathrm{D}_{90}\right)$ & 35.78 & & 30.09 & & 32.17 & \\
\hline \multicolumn{2}{|c|}{ Specific Mass $(\mathrm{g} / \mathrm{cm})$} & 3.11 & & 2.61 & & 3.12 & \\
\hline \multicolumn{2}{|c|}{ Specific Area B.E.T. (m /g) } & 5.79 & & 6.03 & & 6.23 & \\
\hline \multirow{3}{*}{$\begin{array}{l}\text { Compressiv } \\
\text { e Strength } \\
(\mathrm{MPa})\end{array}$} & 3 days & 30.28 & $\geq 15.00$ & 17.11 & $\geq 10.00$ & 29.32 & $\geq 24.00$ \\
\hline & 7 days & 37.58 & $\geq 25.00$ & 20.26 & $\geq 20.00$ & 35.15 & $\geq 34.00$ \\
\hline & 28 days & 42.88 & $\geq 40.00$ & 33.03 & $\geq 32.00$ & 42.08 & - \\
\hline
\end{tabular}
each cement type, in consonance with the NBR 7215 (ABNT, 2019).

Table 1 - Chemical, physical, and mechanical properties to the cement types

Note: LN: Regulatory limit following the NBR 16697 (ABNT, 2018).

212 Silva, D. M. G. da; Cappellesso, V. G.; Garcia, M. G. L.; Masuero, A. B.; Dal Molin, D. C. C. 
Quartz sand, fineness module 1,89, following the NBR 7211 (ABNT, 2009a), density 2,62g/cm , according to NBR NM 52 (ABNT, 2009b) and 1.,30\% water absorption by NBR NM 30 (ABNT, 2001). Mortar mix designs are in Table 2.

Mixture procedures followed the steps described in NBR 7215 (ABNT, 2019). In the fresh state, the flow table index, defined in NBR 13276 (ABNT, 2016), presenting similar behavior to the mortars, with different cement types, was evaluated.

Specimens were producing according to NBR 7215 (ABNT, 2019) and placed in a room at $23 \pm 2{ }^{\circ} \mathrm{C}$ and relative humidity greater than $\geq 95 \%$. At 28 days, the compressive strength, according to NBR 7215 (ABNT, 2019) was performed in specimens for each cement type mortar. Results drew $22.39 \pm 0.46 \mathrm{MPa}, 31.62 \pm 0.99$ $\mathrm{MPa}$, and 23.50 $\pm 0.78 \mathrm{MPa}$, respectively, CPII F, CPIV, and CPV. Additionally, it is important to note that although the CP IV is the one with most significant mechanical strength at 28 days, as shown in Table 1; however, mortars produced with this cement type were those with the lowest mechanical strength at the same age.

\section{Sampling and environmental conditions}

Figure 1 shows the sampling processes at 28 days used in the $\mathrm{Ca}(\mathrm{OH})_{2}$ leached titration and the superficial crack closure analysis. Specimens $(5 \times 10 \mathrm{~cm})$ are divided into five types, each one with $2.0 \mathrm{~cm}$ thickness and $5 \mathrm{~cm}$ in diameter. The cracking method was the Brazilian splitting test, i.e., applied to the upper and lower samples facing a compression strength. Thus, a mid-sample tensile strength occurs, perpendicular to the load application, and a crack appears. Additionally, lateral displacement was limited to prevent a total sample breaking.

This study evaluated not the hydration products, like C-S-H and ettringite, but $\mathrm{Ca}(\mathrm{OH})_{2}$ leached influence on the self-healing products in cracked mortars.

The cracked samples were stored in four environments, during the total analysis period, as shown in the Figure 2. All storage places are supplied with two liters of tap water free from $\mathrm{Ca}(\mathrm{OH})_{2}$ initially. It is important to note that all cracked surfaces, with the largest crack width, were bottom-oriented on plastic grids, avoiding direct contact with the storage containers' bottom. Samples are submitted to the following environmental conditions:

(a) submerged with water renewal (SC): submerse samples with a water renewal process every seven days;

(b) submerged without water renewal (SS): submerse samples in the same water all the time;

(c) wet/dry cycles without water renewal (CS): no water renewal process and samples stayed wet two days submerged in water and five days in dry condition (out of the water), i.e. wet - 2 days and dry - 5 days; and

(d) wet/dry cycles with water renewal (CC): water renewal process and samples stayed wet two days submerged in water and five days in dry condition (out of the water), i.e. wet - 2 days and dry - 5 days;

A water renewal procedure in the SC and CC environments was performed at each new cycle.

The analysis was every seven days as follows:

(a) submerged samples were removed from their environmental condition, air-dried for 4 hours, microscopy imaging, and then exposed again to their condition environment; and

(b) samples in wet-dry cycles, two days wet (submerged), five days drying in the climate room, microscopy imaging, and restarting the cycle.

$\mathrm{Ca}(\mathrm{OH})_{2}$ content analysis took place on the same days as the microscopy imaging for each environmental condition.

Table 2 - Mortar mix designs

\begin{tabular}{c|c|c|c|c}
\hline Sample & Cement & Sand & $\begin{array}{c}\text { Water to cement } \\
\text { ratio }(\mathbf{w} / \mathbf{c})\end{array}$ & $\begin{array}{c}\text { Flow table index } \\
(\mathbf{m m})\end{array}$ \\
\hline CPII F & 1 & 1.37 & 0.40 & 308 \\
CPIV & 1 & 1.37 & 0.40 & 327 \\
CPV & 1 & 1.37 & 0.40 & 320 \\
\hline
\end{tabular}


Figure 1 - Cutting samples and cracking procedure

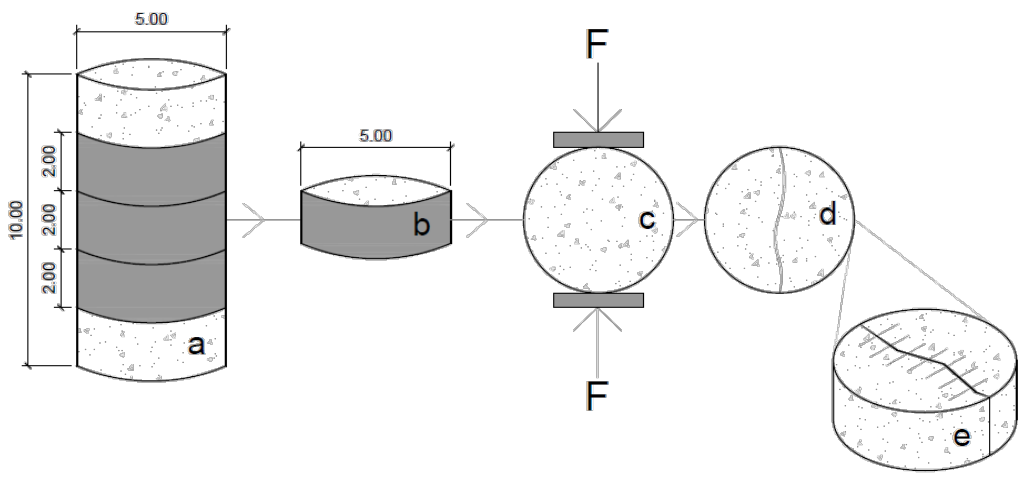

Figure 2 - Environmental conditions, cement types and sample arrangement in the containers

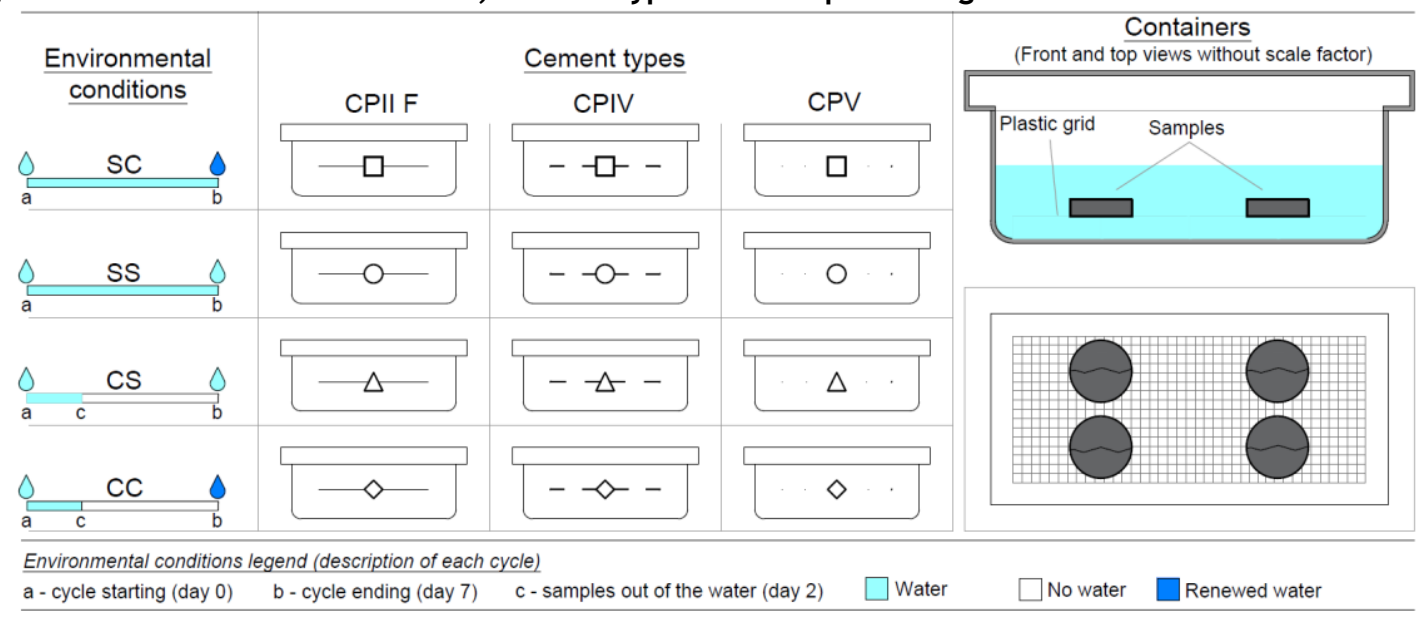

\section{Calcium hydroxide content measurement}

NBR 15895 (ABNT, 2010) specifies a Chapelle Modified Method, used to determine capacity of $\mathrm{Ca}(\mathrm{OH})_{2}$ consumption by a mineral admixture, and this procedure was the base to determine all specific concentrations, and to obtain the linear adjustment. Figure 3 shows a correlation between $\mathrm{Ca}(\mathrm{OH})_{2}$ content and an $\mathrm{HCl} 0.1 \mathrm{~N}$, amount used to neutralize the initial solution.

Seven specific $\mathrm{Ca}(\mathrm{OH})_{2}$ solutions, phenolphthalein-indicated, were titrated with $\mathrm{HCl} 0.1 \mathrm{~N}$ to promote a $\mathrm{pH}$ less than 8 change in alkaline solutions, and it is the basis of this proposed method. When $\mathrm{HCl} 0.1 \mathrm{~N}$ amount is equal to zero, in other words, $\mathrm{pH}$ is less than 8 before the titration, a $0,0036 \mathrm{~g} / \mathrm{mL}$ remains in the Equation 6. However, $\mathrm{Ca}(\mathrm{OH})_{2}$ content is not significant in the solution, and in Results and Discussions item this comment appears as a 'Linear fit limit' in Figures 4 e 5.

$\mathrm{Ca}(\mathrm{OH})_{2}$ content $(\mathrm{g} / \mathrm{mL})=0.0044 . \mathrm{x}+0.0036$

Eq. 6

Where ' $\mathrm{x}$ ' is $\mathrm{HCl} 0.1 \mathrm{~N}$ amount.

In this approach, the unique Portlandite source was from the hardened mortar matrices available, and it was the single-agent able to promote a $\mathrm{pH}$ change in the environmental exposure conditions. Initially, each container stored four samples $(\varnothing=50 \mathrm{~mm}, \mathrm{~h}=20 \mathrm{~mm})$ in two liters of tap water (neutral $\mathrm{pH})$. Two samples, 20 $\mathrm{mL}$ each, at each cycle (7 days), were extracted from containers to determine the $\mathrm{Ca}(\mathrm{OH})_{2}$ content by titration as proposed in Figure 3. The reservoirs containing the samples remained closed throughout the analysis period, ensuring no water changes with the environment.

\section{Sample and self-healing imaging analysis}

A Zeiss Stemi 508 optical microscope, with a maximum magnification of 250x, was used to follow the superficial cracking closure. Six images described each cracked sample, and a digital analysis software (imageJ) was used to process all images and create a unique crack from six images, as shown in Figure 4.

214 Silva, D. M. G. da; Cappellesso, V. G.; Garcia, M. G. L.; Masuero, A. B.; Dal Molin, D. C. C. 
Figure 3 - Calcium hydroxide content measurement in linear adjustments based on specific concentrations

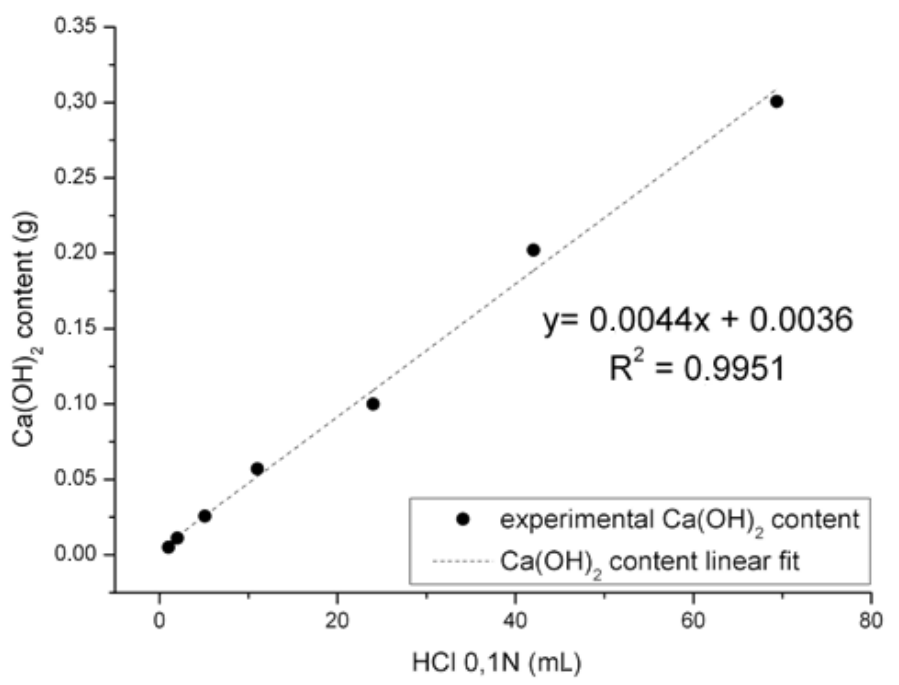

Figure 4 - Focus area in a crack analyzed, the crack opening measurements were on a central common point for the chosen region - a CPV sample in SS atmosphere is the bottom selected as an example

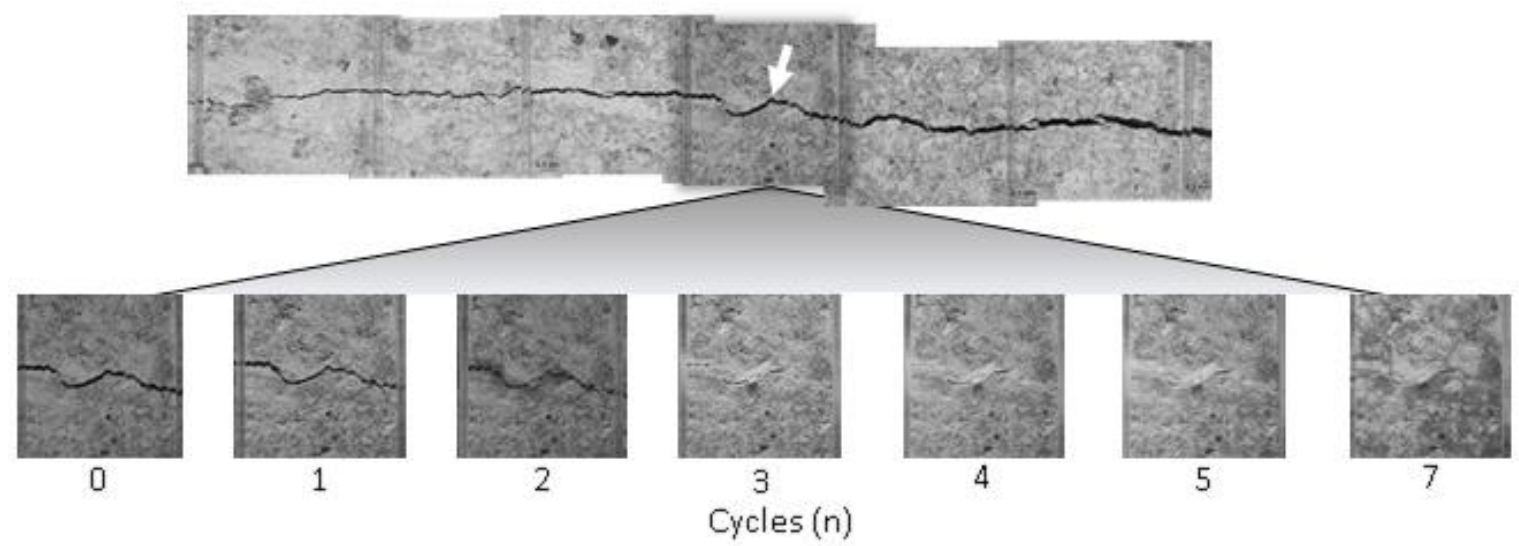

Different crack widths can be observed at both ends of the same crack, and because of the mechanical stress during the cracking process. Thus, the central portion, which represents an average opening width in each sample studied, was taken for crack width measurements, indicate by the arrow in Figure 4 . Reference cracks were measured by microscope analysis immediately after the crack opening process, describing the initial crack width (cycle 0), and at multiple seven days ages (cycles 1, 2, 3, 4, 5 and 7). Therefore, Equation 7 defines how to obtain the Crack width Index (I).

$I=\frac{W_{n}}{W_{i}}$

Crack width Index $(I)$ is a ratio between the crack opening in the cycle under analysis $\left(\mathrm{W}_{\mathrm{n}}\right)$ and the crack opening in the initial instant $\left(\mathrm{W}_{\mathrm{i}}\right)$. Thus, $I$ is a quantitative index that expresses the crack closure over time. An $I$ index is a two samples average, with equivalent initial crack widths for each composition analyzed.

\section{Results and discussions}

Figure 5 shows the calcium hydroxide content, $\mathrm{Ca}(\mathrm{OH})_{2}$, in each exposure environment, for the different cement types. The submerged condition without water renewal (SS), in the Figure 4 upper right part, illustrates that for $\mathrm{CPV}$ cement the highest content of $\mathrm{Ca}(\mathrm{OH})_{2}$ leached in its exposure environment, both at the beginning and over time. Measurements demonstrated a calcium hydroxide in non-renewal environments (SS and CS) high level. The $\mathrm{Ca}(\mathrm{OH})_{2}$ content comes from the leaching process in the cement-based matrices 
minus the consumed amount by carbonation reactions since water is the same throughout all cycles for that analysis condition. Thus, the reduction in the concentration of $\mathrm{Ca}(\mathrm{OH})_{2}$ in the exposure environments induces the understanding that its consumption took place through Equations 4 and 5, resulting in healing products joined in the cement matrix.

Wet/dry cycles contribute to the leached calcium hydroxide, present on the sample surface and inside the cracks, by carbonation. Thus, when placed again in the wet condition, the $\mathrm{Ca}(\mathrm{OH})_{2}$ leached reduces due to the carbonation reactions. Given the above, Figure 5 shows wet/dry exposure conditions, both with renewal (CC) and without renewal (CS), the $\mathrm{Ca}(\mathrm{OH})_{2}$ content tends to be constant earlier when compared to the submerged conditions (SS and SC) and this can be explained by the lower humidity present in these exposure environments. Steiner et al. (2020) stated that portlandite in environments with lower relative humidity and a source of $\mathrm{CO}_{2}$ can produce a layer of $\mathrm{CaCO}_{3}$ around its particle, making its solubilization impossible. After evaluating renewal water wet/dry cycles, Figure $5(\mathrm{CC})$, in the second cycle, a $\mathrm{Ca}(\mathrm{OH})_{2}$ content is below the significance level for all cement types and remains constant up to the end of the test. Thus, it issuggested that the water exchange with the samples' environment did not allow more leached $\mathrm{Ca}(\mathrm{OH})_{2}$ to be detected by the proposed methodology. In the CS condition, without water renewal, the first cycle had similar behavior as in the $\mathrm{CC}$ condition. However, in $\mathrm{CC}$, water is not renewed, and $\mathrm{Ca}(\mathrm{OH})_{2} \mathrm{was}$ probably consumed by carbonation reactions, as shown in the curve decline in Figure 5 (CS), where a decrease of the $\mathrm{Ca}(\mathrm{OH})_{2}$ content is evident. The CPII F cement presented a higher content of $\mathrm{Ca}(\mathrm{OH})_{2}$ leached in the first two CS cycles than the CPIV cement. Also, CPIV samples provide higher levels of $\mathrm{Ca}(\mathrm{OH})_{2}$ leached than the CPII F samples, in the submerged conditions (SS and SC). This fact may be associated with the smaller CPII F particle sizes.

Figure 5 - $\mathrm{Ca}(\mathrm{OH})_{2}$ content $(\mathrm{g} / \mathrm{mL})$ in several environmental conditioning SC (submerged with water renewal) at the top left, SS (submerged without water renewal) at the top right, CS (cycles without water renewal at the bottom left), and CC (cycles with water renewal) at the bottom right with the linear fit limit for different cement types, at the 0 to 7 cycles

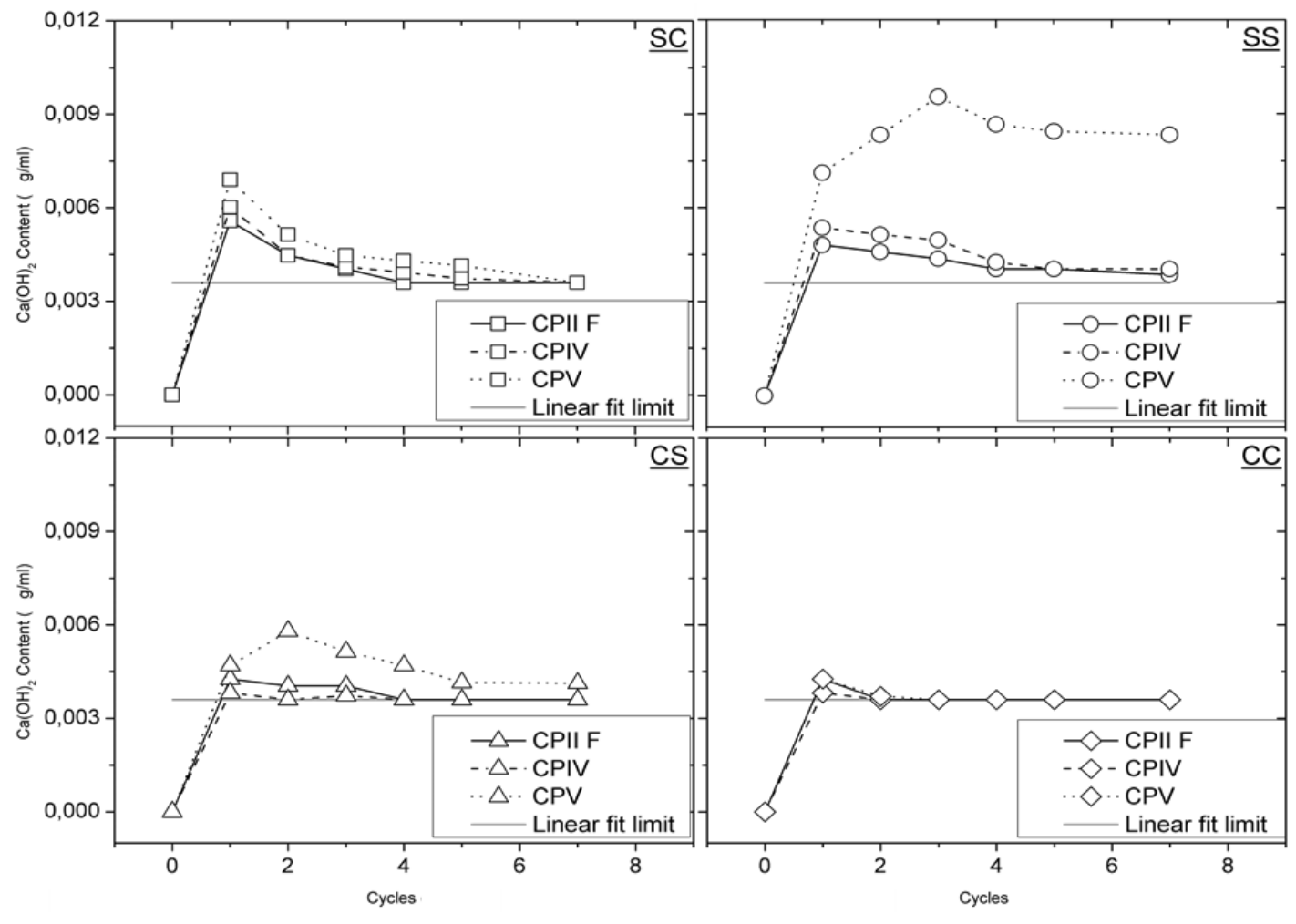

216 Silva, D. M. G. da; Cappellesso, V. G.; Garcia, M. G. L.; Masuero, A. B.; Dal Molin, D. C. C. 
Figure 5 shows $\mathrm{Ca}(\mathrm{OH})_{2}$ content grouped by cement type in the environmental conditions. CPV cement was the one that presented the highest $\mathrm{Ca}(\mathrm{OH})_{2}$ for the submerged without renewal water (SS) condition, followed by the submerged condition with water renewal (SC). However, the CPV cement presented a lower $\mathrm{Ca}(\mathrm{OH})_{2}$ concentration for the cycle conditions, being lower than the CPII F and CPIV. A possible fact to explain this behavior is the cement chemical compositions. The CPV cement, a high initial strength cement, has in its composition, a higher amount of alite $\left(\mathrm{C}_{3} \mathrm{~S}\right)$ available for hydration reactions. The $\mathrm{C}_{3} \mathrm{~S}$ hydration produces more $\mathrm{Ca}(\mathrm{OH})_{2}$ than the $\mathrm{C}_{2} \mathrm{~S}$ hydration (MEHTA; MONTEIRO, 2014), as described in the Equations 1 and 2. It is known that the $\mathrm{Ca}(\mathrm{OH})_{2}$ production for autogenous self-healing has a significant impact on the cracking closure through the calcium carbonate sealing, resulting from the carbonation of $\mathrm{Ca}(\mathrm{OH})_{2}$ (HUANG et al., 2016; QIAN; ZHOU; SCHLANGEN, 2010; REINHARDT et al., 2013; SISOMPHON; COPUROGLU; KOENDERS, 2013).

Higher $\mathrm{Ca}(\mathrm{OH})_{2}$ concentrations were observed in exposure environments containing $\mathrm{CPV}$, although a similar behavior was expected for CPII F, as both cement types present in their composition clinker as the only chemically active component in water presence. Considering clinker fractions in CPV and CPII F cements, respectively, equal to $90-100 \%$ and $75-89 \%$, it may be the primary purpose of a lower amount of $\mathrm{Ca}(\mathrm{OH})_{2}$ able to leaching in CPII F cement.

Submerged conditions were those with the highest $\mathrm{Ca}(\mathrm{OH})_{2}$ content leached for all cements, this behavior supports the evidence reported in many studies that show better performance of autogenous self-healing phenomenon for submerged conditions (BORG et al., 2018; CUENCA; TEJEDOR; FERRARA, 2018; FERRARA; KRELANI; CARSANA, 2014; HUANG et al., 2016; ROIG-FLORES et al., 2015; SISOMPHON; COPUROGLU; KOENDERS, 2013). There were different amounts in initial $\mathrm{Ca}(\mathrm{OH})_{2}$ leached for the submerged conditions with and without water renewal (SS and SC). However, this behavior has equivalent amounts and may be associated with inevitable variances in the crack's geometry and tortuosity. Thus, although the crack widths are similar to each other (less than $2 \mathrm{~mm}$ ), these variations are practically impossible to control in the cracking process and are usually neglected in several studies related to autogenous healing of cracks in cementitious matrices (AKHAVAN; SHAFAATIAN; RAJABIPOUR, 2012; VAN MULLEM et al., 2019).

CPIV samples in $\mathrm{CC}$ condition were the one with the lowest $\mathrm{Ca}(\mathrm{OH})_{2}$ leached content, remaining at the lower limit (linear fit limit) since the first cycle, as reported in Figure 6 (CPIV). Pozzolanic reactions in binders with a chemically active mineral admixture, as CPIV, are the main fact of a lower concentration of $\mathrm{Ca}(\mathrm{OH})_{2}$ leached and available in the environment. This chemical reaction consists of the secondary C-S-H formation from the $\mathrm{Ca}(\mathrm{OH})_{2}$ produced by the clinker hydration and the pozzolanic addition present in the CPIV. Therefore, $\mathrm{Ca}(\mathrm{OH})_{2}$ leaching does not occur, and this compound relies not on the environment. However, the internal cracks closure predominates with the secondary C-S-H instead calcite production formation of calcite (HUANG; YE; DAMIDOT, 2014; ZHANG; QIAN; MA, 2014). Cappellesso (2018) observed internal matrix densification, through non-destructive techniques (ultrasonic waves test), in a wet/dry cycle environment, resulting probably from the C-S-H secondary for the same cement type.

The cracking closure evaluated through optical microscope and the crack width index (I) to exposure environments are reported in Figure 7. Note that the first value in each graphic is equal to 1, and this is explained in the Equation 7.

Figure $6-\mathrm{Ca}(\mathrm{OH})_{2}$ content $(\mathrm{g} / \mathrm{mL})$ of different cement types, CPII $\mathrm{F}$ on the left, CPIV in the middle and $\mathrm{CPV}$ on the right with the linear fit limit in several environmental conditioning

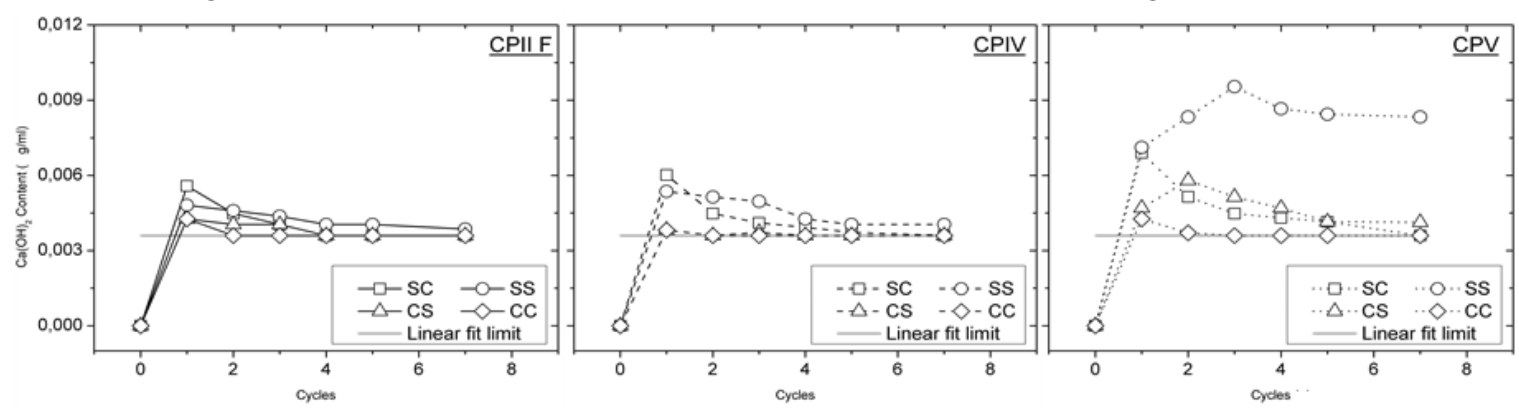


Figure 7 - Crack width index (I) in various environmental conditions SC (submerged with water renewal) at the top left, SS (submerged without water renewal) at the top right, CS (cycles without water renewal) at the bottom left, and CC (cycles with water renewal) at the bottom right with the linear fit limit to different cement types
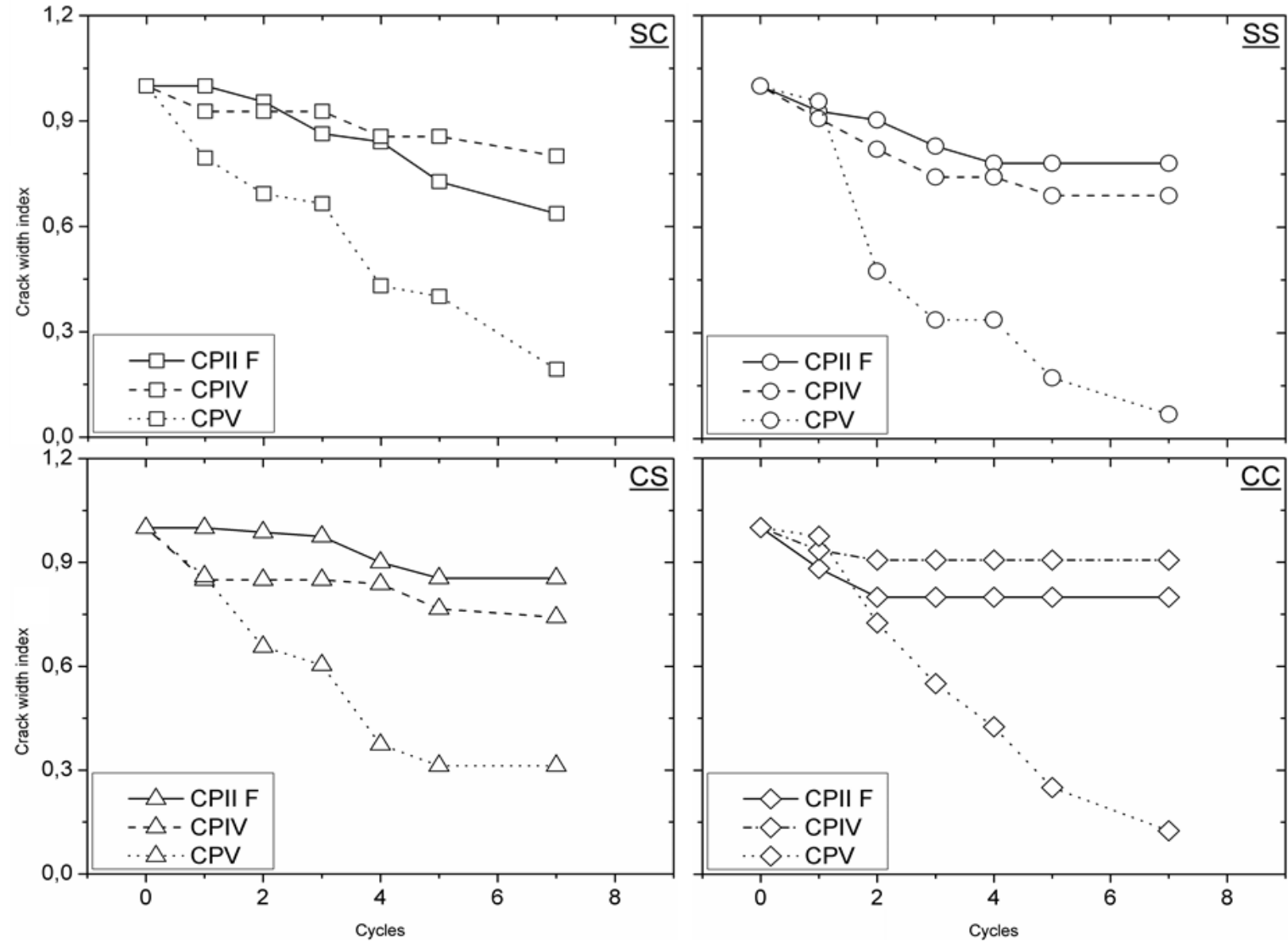

CPV samples were those with the highest crack width index (I) for all exposure conditions. Thus, regarding this behavior, it is observed that:

(a) in this cement type composition, according to NBR 16697 (ABNT, 2018), no chemically reactive mineral admixtures are allowed, as previously discussed; and

(b) Huang et al. (2016) stated that regions with higher $\mathrm{Ca}^{2+}$ ions content are subject to higher healing product formations. Given the above, analyzing the $\mathrm{Ca}(\mathrm{OH})_{2}$ concentrations presented in Figure 5 , the higher closure presented by CPV may be justified.

CPII F and CPIV samples demonstrated a close behavior to each other. Under the submerged exposure conditions, SS and SC, samples containing CPII F and CP IV showed higher $I$ index than those in wet/dry cycles, CC and CS. Thus, as suggested by Jiang, Li and Yuan (2015), and Suleiman, Nelson and Nehdi (2019), the exposure environment influences significantly the self-healing phenomenon, and a water source available is a primary factor for its occurrence. Ferrara et al. (2017) and Roig-Flores et al. (2015) approaches show that wet/dry cycles can also show significant results in crack sealing, however, in this approach, as shown in Figure 6, submerged conditions were more efficient.

CPII F samples, according to NBR 16697 (ABNT, 2018), is a blended cement made of clinker and limestone (11 to 25\%). Suleiman, Nelson and Nehdi (2019) found by ICP-AES (Inductively Coupled Plasma - Atomic Emission Spectroscopy) high calcium hydroxide leached into the liquid surrounding Portland cement mortar samples with limestone additions. Thus, although low concentrations of leached calcium hydroxide were observed in samples made with this cement type, a higher crack width index $(I)$ was obtained in samples exposed to conditions with water renewal (SC and $\mathrm{CC}$ ) than in CPIV samples. In conditions without water renewal and, consequently, higher concentrations of $\mathrm{Ca}(\mathrm{OH})_{2}$, a higher I index is observed for CPIV samples probably because of the C-S-H, as a product from pozzolanic reactions. Cappellesso (2018) evaluated concrete samples with a 0.50 water to cement ratio $(\mathrm{w} / \mathrm{c})$ in wet/dry cycles and found a reduced superficial

218 Silva, D. M. G. da; Cappellesso, V. G.; Garcia, M. G. L.; Masuero, A. B.; Dal Molin, D. C. C. 
cracking closure for CPIV matrices. Ahn and Kishi (2010) stated that the autogenous self-healing process can be improved in cement-based matrices with mineral admixtures. Thus, the superficial cracking closure is not sufficient to describe the self-healing phenomenon because it can occur at depth and not near the crack mouth.

In Figure 8, CPV samples showed the highest Crack Width Index (I) in function of the different environmental conditions grouped by type of cement. Sisomphon, Capuroglu and Koenders (2013) described the autogenous healing phenomenon in cement-based matrices directly associated with the presence of $\mathrm{Ca}^{2+}$ ions in the environment. Thus, the cracking closure observed is consistent with the results obtained and presented in Figure 8 (CPV), showing for the submerged condition without water renewal (SS) the higher availability of $\mathrm{Ca}(\mathrm{OH})_{2}$ in cycle 7 and the higher crack closure at the same age $(\mathrm{I}=0.03$; crack closure $=97 \%$ ).

Microscopy results for CPII F samples cannot describe expected behavior over time. Samples in submerged conditions (SC and CS) were those that, respectively, presented the largest and the smallest cracking sealing. A correlation between the $\mathrm{Ca}(\mathrm{OH})_{2}$ leached content, Figure 5 (CPII F), and the superficial cracking closure, Figure 8 (CPII F), cannot be established.

CPIV samples had similar behavior in different exposure environments. At the final cycle (7), i.e., at 49 days, the Crack Width Index (I) presented the following order $\mathrm{SS}>\mathrm{CS}>\mathrm{CC}$, showing for samples in submerged without water renewal (SS) condition, the highest cracking closure. Vieira and Dal Molin (2011) evaluated similar cement-based matrices at 7 days as crack opening age and obtained relevant healing properties. Thus, it is evident that the cracking age is an essential factor to be considered in the autogenous self-healing evaluation, since the presence of anhydrous grains of cement influence in the speed and magnitude of cracks sealing.

This research did not evaluate the volume and pore distribution in the matrix, but its knowledge is specifically relevant to analyze autogenous self-healing in cement-based materials. Concerning CPII F samples, with a large amount of limestone filler and fine grains, a more significant pore volume decrease, and matrix densification can be induced by hydration products. Although a similar behavior between CPII F and CPV samples was expected, pores sealing may have decreased the possibility of leachable materials to be found in the environment. That is, only $\mathrm{Ca}(\mathrm{OH})_{2}$ in the cracks' surfaces and capillary porosity will be able to dissolve in water. $\mathrm{Ca}(\mathrm{OH})_{2}$ content present in dense or filled pores will not be released in the environment surrounding the samples. Therefore, although the CPV samples present higher $\mathrm{Ca}(\mathrm{OH})_{2}$ leachable and cracking closure, its use would be not the best choice, because of an increase in permeability. Thus, changes in porosity and interconnecting pores can happen and decrease the durability of CPV cementbased materials. Secondary C-S-H from pozzolanic reactions in CPIV may contribute to a porosity refinement in cementitious matrices. However, it does not present a very sharp cracking closure and higher levels of $\mathrm{Ca}(\mathrm{OH})_{2}$ leached than CPV samples, because of the lower clinker content in CPIV respect to CPV cement. It is known that cracks are a preferred pathway for aggressive agents, but the fact that it has a higher closing potential does not outweigh the consequence of the reduction in permeability. Fibers in the cementitious matrix can achieve greater control over the crack opening; however, an additional variable is inserted into the system and needs additional attention.

Finally, cements types with higher pozzolanic content, like CPIV cement type, despite the late mechanical strength gain and lower cracking closure potential, may present durability increases than other cement types, due to the porosity refinement and not to its superficial self-healing ability.

Figure 8 - Crack width index (I) of different cement types, CPII F on the left, CPIV in the middle and $\mathrm{CPV}$ on the right with the linear fit limit in various environmental conditioning

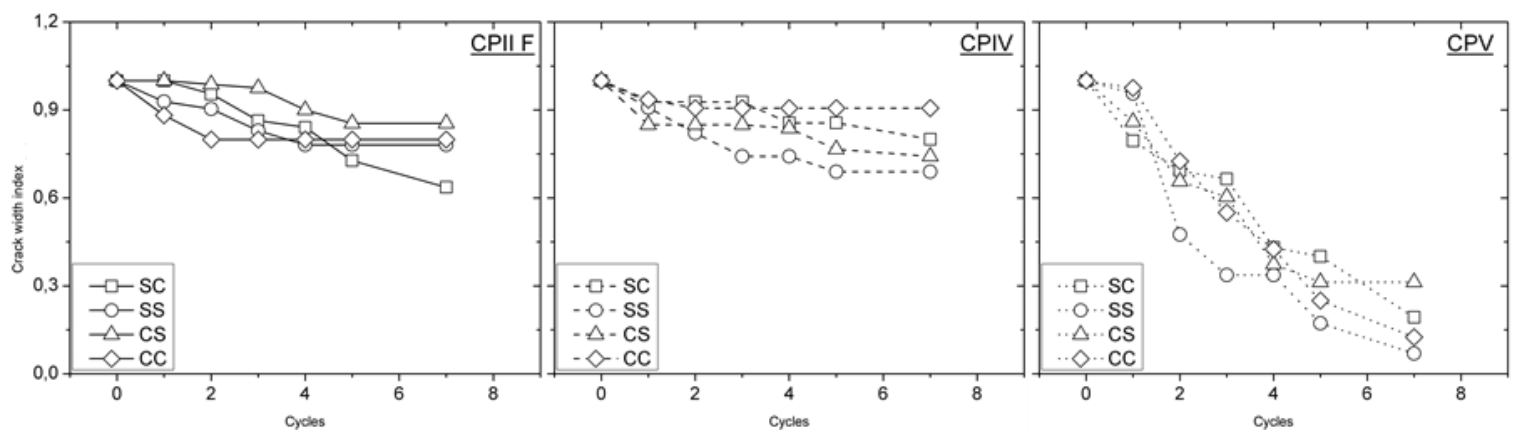




\section{Conclusions}

The influence of calcium hydroxide leached in mortars cracked at 28 days for three different cement types was analyzed: cement with limestone (CPII F), pozzolanic cement (CPIV) and high initial strength cement (CPV). Under four different environmental conditions, the specimens were conditioned: submerged with water renewal (SC), submerged without water renewal (SS), cycles without water renewal (CS), and cycles with water renewal (CC). The cement chemical composition has an important influence on autogenous selfhealing ability. Types of cement with a higher pozzolanic material content presented a lower concentration of $\mathrm{Ca}(\mathrm{OH})_{2}$ leached in the environment, as previously expected. Pozzolanic reactions, happened in cement with chemically active mineral additions, and consumed the leachable calcium hydroxide. Thus the cracks closure may occurred inside the cracks, and thus were not detectable by optical microscopy observations.

On the other hand, types of cement with a higher clinker content, like the high initial resistance (CPV) cement, have a higher formation of $\mathrm{Ca}(\mathrm{OH})_{2}$ and, therefore, a higher amount of leachable material, which increases the availability of calcium ions in solution. Thereby, the top closure becomes more evident. Hence, the specimens with CPV cement had a crack closure of $97 \%$ in the submerged without water renewal (SS).

Mortars produced with CPII F cement did not present a similar behavior to those produced with CPV, as expected from its chemical composition.

Regarding the exposure conditions evaluated, the submerged one without water renewal had a higher concentration of calcium hydroxide, as well as higher superficial closure of cracks. This result is in agreement with the literature which states that the higher the content of $\mathrm{Ca}^{2+}$ ions leached from the matrix and present in the environment, the higher the healing capacity.

\section{References}

AHN, T. H.; KISHI, T. Crack self-healing behavior of cementitious composites incorporating various mineral admixtures. Journal of Advanced Concrete Technology, v. 8, n. 2, p. 171-186, 2010.

AKHAVAN, A.; SHAFAATIAN, S. M. H.; RAJABIPOUR, F. Quantifying the effects of crack width, tortuosity, and roughness on water permeability of cracked mortars. Cement and Concrete Research, v. 42, n. 2, p. 313-320, 2012.

AMERICAN SOCIETY FOR TESTING AND MATERIALS. C595/C595M: standard specification for blended hydraulic cements. West Conshohocken, 2018.

AMERICAN SOCIETY FOR TESTING AND MATERIALS. C150/C150M: standard specification for portland Cement. West Conshohocken, 2019.

ANGLANI, G.; TULLIANI, J. M.; ANTONACI, P. Behaviour of pre-cracked self-healing cementitious materials under static and cyclic loading. Materials, v. 13, n. 5, p. 16-23, 2020.

ARAÚJO, M. et al. Poly(methyl methacrylate) capsules as an alternative to the proof-of-concept' glass capsules used in self-healing concrete. Cement and Concrete Composites, v. 89, p. 260-271, 2018.

ARNDT, J. A. Avaliação de aditivos cristalizantes na autocicatrização de concretos de cimento portland. Porto Alegre, 2019. Dissertação (Mestrado em Engenharia Civil) -Escola de Engenharia, Universidade Federal do Rio Grande do Sul, Porto Alegre, 2019.

ASSOCIAÇÃO BRASILEIRA DE NORMAS TÉCNICAS. NBR NM 30: agregado miúdo: determinação da absorção de água. Rio de Janeiro, 2001.

ASSOCIAÇÃO BRASILEIRA DE NORMAS TÉCNICAS. MBR NM 52: agregado miúdo: determinação de massa específica e massa específica aparente. Rio de Janeiro, $2009 \mathrm{~b}$.

ASSOCIAÇÃO BRASILEIRA DE NORMAS TÉCNICAS. NBR 15895: materiais pozolânicos: determinação do teor de hidróxido de cálcio fixado: método Chapelle modificado. Rio de Janeiro, 2010.

ASSOCIAÇÃO BRASILEIRA DE NORMAS TÉCNICAS. NBR 13276: argamassa para assentamento e revestimento de paredes e tetos: determinação do índice de consistência. Rio de Janeiro, 2016.

ASSOCIAÇÃO BRASILEIRA DE NORMAS TÉCNICAS. NBR 16697: cimento Portland: requisitos. Rio de Janeiro, 2018. 
ASSOCIAÇÃO BRASILEIRA DE NORMAS TÉCNICAS. NBR 7211: agregados para concreto: especificação. Rio de Janeiro, 2009a.

ASSOCIAÇÃO BRASILEIRA DE NORMAS TÉCNICAS. NBR 7215: cimento Portland: determinação da resistência à compressão de corpos de prova cilíndricos. Rio de Janeiro, 2019.

BORG, R. P. et al. Crack sealing capacity in chloride-rich environments of mortars containing different cement substitutes and crystalline admixtures. Journal of Sustainable Cement-Based Materials, v. 7, n. 3, p. 141-159, 2018.

BULLER, A. S. et al. Mechanical recovery of cracked fiber-reinforced mortar incorporating crystalline admixture, expansive agent, and geomaterial. Advances in Materials Science and Engineering, v. 2019, 2019.

CAPPELLESSO, V. G. Uso de impermeabilizante por cristalização para redução da permeabilidade do concreto. Porto Alegre, 2016. Trabalho de Conclusão de Curso (Monografia) - Escola de Engenharia, Universidade Federal do Rio Grande do Sul, Porto Alegre, 2016.

CAPPELLESSO, V. G. Avaliação da autocicatrização de fissuras em concretos com diferentes cimentos. Porto Alegre, 2018. Dissertação (Mestrado em Engenharia Civil) - Escola de Engenharia, Universidade Federal do Rio Grande do Sul, Porto Alegre, 2018.

CHEN, J.; YE, G. A Lattice Boltzmann single component model for simulation of the autogenous selfhealing caused by further hydration in cementitious material at mesoscale. Cement and Concrete Research, v. 123, p. 1-9, apr. 2019.

CUENCA, E.; TEJEDOR, A.; FERRARA, L. A methodology to assess crack-sealing effectiveness of crystalline admixtures under repeated cracking-healing cycles. Construction and Building Materials, v. 179, p. 619-632, 2018.

DA SILVA, F. B. et al. Production of non-axenic ureolytic spores for self-healing concrete applications. Construction and Building Materials, v. 93, p. 1034-1041, 2015.

DE MUYNCK, W.; DE BELIE, N.; VERSTRAETE, W. Effectiveness of admixtures, surface treatments and antimicrobial compounds against biogenic sulfuric acid corrosion of concrete. Cement and Concrete Composites, v. 31, n. 3, p. 163-170, 2009.

DE NARDI, C. et al. Effect of age and level of damage on the autogenous healing of lime mortars.

Composites Part B: Engineering, v. 124, p. 144-157, 2017.

DOUBLE, D. D.; HELlAWELL, A.; PERRY, S. J. Hydration of Portland Cement. Proceedings of the Royal Society of London, v. 359, n. 1699, p. 435-451, 1978.

DRY, C. Procedures developed for self-repair of polymer matrix composite materials. Composite Structures, v. 35, n. 3, p. 263-269, 1996.

EDVARDSEN, C. Water permeability and autogeneous healing of cracks in concrete. ACI Materials Journal, v. 96, n. 4, p. 448-454, 1999.

ERSAN, Y. et al. Self-protected nitrate reducing culture for intrinsic repair of concrete cracks. Frontiers in Microbiology, v. 6, nov. 2015.

ERŞAN, Y. Ç. et al. Nitrite producing bacteria inhibit reinforcement bar corrosion in cementitious materials. Scientific Reports, v. 8, n. 1, p. 2-11, 2018.

FERRARA, L. et al. Effects of autogenous healing on the recovery of mechanical performance of High Performance Fibre Reinforced Cementitious Composites (HPFRCCs): part 1. Cement and Concrete Composites, v. 83, p. 76-100, 2017.

FERRARA, L. et al. Experimental characterization of the self-healing capacity of cement based materials and its effects on the material performance: a state of the art report by COST Action SARCOS WG2. Construction and Building Materials, v. 167, p. 115-142, 2018.

FERRARA, L.; KRELANI, V.; CARSANA, M. A “fracture testing" based approach to assess crack healing of concrete with and without crystalline admixtures. Construction and Building Materials, v. 68, p. 535$551,2014$. 
FERRARA, L.; KRELANI, V.; MORETTI, F. On the use of crystalline admixtures in cement based construction materials: from porosity reducers to promoters of self healing. Smart Materials and Structures, v. 25, n. 8, 2016.

GONZÁLEZ, Á. et al. Evaluation of Portland and Pozzolanic cement on the self-healing of mortars with calcium lactate and bacteria. Construction and Building Materials, v. 257, p. 1-11, 2020.

HUANG, H. et al. Self-healing in cementitious materials: materials, methods and service conditions. Materials and Design, v. 92, p. 499-511, 2016.

HUANG, H.; YE, G. Self-healing of cracks in cement paste affected by additional Ca2+ ions in the healing agent. Journal of Intelligent Material Systems and Structures, v. 26, n. 3, p. 309-320, 2015.

HUANG, H.; YE, G.; DAMIDOT, D. Effect of blast furnace slag on self-healing of microcracks in cementitious materials. Cement and Concrete Research, v. 60, p. 68-82, 2014.

HUANG, H.; YE, G.; PEL, L. New insights into autogenous self-healing in cement paste based on nuclear magnetic resonance (NMR) tests. Materials and Structures/Materiaux et Constructions, v. 49, n. 7, p. 2509-2524, 2016.

JIANG, Z.; LI, W.; YUAN, Z. Influence of mineral additives and environmental conditions on the selfhealing capabilities of cementitious materials. Cement and Concrete Composites, v. 57, p. 116-127, 2015.

LI, M. et al. Bio-consolidation of cracks in masonry cement mortars by Acinetobacter sp. SC4 isolated from a karst cave. International Biodeterioration and Biodegradation, v. 141, p. 94-100, nov. 2019.

MAES, M.; SNOECK, D.; DE BELIE, N. Chloride penetration in cracked mortar and the influence of autogenous crack healing. Construction and Building Materials, v. 115, p. 114-124, 2016.

MEHTA, P. K.; MONTEIRO, P. J. M. Concreto: estruturas, propriedades e materiais. In: HASPARYK, N. P. (ed). Concreto, microestrutura e materiais. São Paulo: IBRACON, 2014.

MINNEBO, P. et al. A novel design of autonomously healed concrete: towards a vascular healing network. Materials, v. 10, n. 1, p. 1-23, 2017.

MOSTAVI, E. et al. Evaluation of self-healing mechanisms in concrete with double-walled sodium silicate microcapsules. Journal of Materials in Civil Engineering, v. 27, n. 12, p. 1-8, 2015.

NISHIWAKI, T. et al. Experimental study on self-healing capability of FRCC using different types of synthetic fibers. Journal of Advanced Concrete Technology, v. 10, n. 6, p. 195-206, 2012.

PECCHIO, M. A influência de fósforo, enxofre e estrôncio na mineralogia do clínquer Portland. São Paulo, 2013. Dissertação (Mestrado em Engenharia Civil) - Programa de Pós-graduação em Mineralogia e Petrologia, Universidade de São Paulo, São Paulo, 2013.

QIAN, S. Z.; ZHOU, J.; SCHLANGEN, E. Influence of curing condition and precracking time on the selfhealing behavior of Engineered Cementitious Composites. Cement and Concrete Composites, v. 32, n. 9 , p. 686-693, 2010.

REINHARDT, H. W. et al. Recovery against mechanical actions. In: DE ROOIJ, M. R. et al. (org.). Selfhealing phenomena in cement-based materials. Amsterdam: RILEM, 2013.

ROIG-FLORES, M. et al. Self-healing capability of concrete with crystalline admixtures in different environments. Construction and Building Materials, v. 86, p. 1-11, 2015.

SÁNCHEZ, M. et al. External treatments for the preventive repair of existing constructions: a review. Construction and Building Materials, v. 193, p. 435-452, 2018.

SCHLANGEN, E.; JOSEPH, C.; DE ROOIJ, M. R. Introduction to self-healing materials. In: DE ROOIJ, M. R. et al. (org.). Self-Healing Phenomena in Cement-Based Materials. Amsterdam: RILEM, 2013.

SELVARAJOO, T. et al. Mechanical response of a vascular self-healing cementitious material system under varying loading conditions. Construction and Building Materials, v. 254, p. 1-18, 2020.

SILVA, D. M. G. da. Avaliação do comportamento de polímeros superabsorventes com distintos níveis de pré-saturação em matrizes cimentícias. Porto Alegre, 2018. Dissertação (Mestrado em Engenharia Civil) - Escola de Engenharia, Universidade Federal do Rio Grande do Sul, Porto Alegre, 2018. 
SISOMPHON, K.; COPUROGLU, O.; KOENDERS, E. A. B. Effect of exposure conditions on self healing behavior of strain hardening cementitious composites incorporating various cementitious materials. Construction and Building Materials, v. 42, p. 217-224, 2013.

SNOECK, D. et al. Self-healing cementitious materials by the combination of microfibres and superabsorbent polymers. Journal of Intelligent Material Systems and Structures, v. 25, n. 1, p. 13-24, 2014.

SNOECK, D.; PEL, L.; DE BELIE, N. Autogenous healing in cementitious materials with superabsorbent polymers quantified by means of NMR. Scientific Reports, v. 10, n. 1, p. 1-6, 2020.

STEINER, S. et al. Effect of relative humidity on the carbonation rate of portlandite, calcium silicate hydrates and ettringite. Cement and Concrete Research, v. 135, p. 1-17, may 2020.

SULEIMAN, A. R.; NEHDI, M. L. Effect of environmental exposure on autogenous self-healing of cracked cement-based materials. Cement and Concrete Research, v. 111, p. 197-208, jul. 2018.

SULEIMAN, A. R.; NELSON, A. J.; NEHDI, M. L. Visualization and quantification of crack self-healing in cement-based materials incorporating different minerals. Cement and Concrete Composites, v. 103, p. 4958, apr. 2019.

VAN BELLEGHEM, B. et al. Effect of polyurethane viscosity on self-healing efficiency of cementitious materials exposed to high temperatures from sun radiation. Journal of Materials in Civil Engineering, v. 30, n. 7, p. 04018145-1 - 04018145-12, 2018.

VAN MULLEM, T. et al. Novel active crack width control technique to reduce the variation on water permeability results for self-healing concrete. Construction and Building Materials, v. 203, p. 541-551, 2019.

VAN TITTELBOOM, K.; DE BELIE, N. Self-healing in cementitious materials: a review. Materials, v. 6, p. 2182-2217, 2013

VIEIRA, G. L. Influência da microfissuração causada por carregamento precoce nas propriedades mecânicas de concretos produzidos com diferentes tipos de cimento. Porto Alegre, 2008. Tese

(Doutorado em Engenharia Civil) - Escola de Engenharia, Universidade Federal do Rio Grande do Sul, Porto Alegre, 2008.

VIEIRA, G. L.; DAL MOLIN, D. C. C. Avaliação da resistência à compressão, resistência à tração e formação de microfissuras em concretos produzidos com diferentes tipos de cimentos, quando aplicado um pré-carregamento de compressão. Ambiente Construído, Porto Alegre, v. 11, n. 1, p. 25-40, jan./mar. 2011.

YANG, Y.; YANG, E. H.; LI, V. C. Autogenous healing of engineered cementitious composites at early age. Cement and Concrete Research, v. 41, n. 2, p. 176-183, 2011.

ZHANG, Z.; QIAN, S.; MA, H. Investigating mechanical properties and self-healing behavior of microcracked ECC with different volume of fly ash. Construction and Building Materials, v. 52, p. 17-23, 2014.

\section{Acknowledgements}

Authors are thankful to CAPES and CNPq for financial support, to Laboratório de Materiais e Tecnologia do Ambiente Construído (LAMTAC) and to Núcleo Orientado à Inovação da Edificação (NORIE), Federal University of the Rio Grande do Sul (UFRGS), for the infrastructure and inputs intended for this research. 


\section{Deividi Maurente Gomes da Silva}

Departamento de Engenharia Civil | Universidade Federal do Rio Grande do Sul | Rua Osvaldo Aranha, 99, sala 706, Centro Histótico |

Porto Alegre - RS - Brasil | CEP 90035-190 | Tel.: (51) 3308-3321 | E-mail: deividi.maurente@gmail.com

Vanessa Giaretton Cappellesso

Departamento de Engenharia Civil | Universidade Federal do Rio Grande do Sul | E-mail: vgcappellesso@gmail.com

Maurício Germano Lopes Garcia

Departamento de Engenharia Civil | Universidade Federal do Rio Grande do Sul | Email: mauricio.lopes.garcia@hotmail.com

Angela Borges Masuero

Departamento de Engenharia Civil | Universidade Federal do Rio Grande do Sul | E-mail: angela.masuero@ufrgs.br

Denise Carpena Coitinho Dal Molin

Departamento de Engenharia Civil | Universidade Federal do Rio Grande do Sul | Email: dmolin@ufrgs.br

\section{Ambiente Construído}

Revista da Associação Nacional de Tecnologia do Ambiente Construído

Av. Osvaldo Aranha, $99-3^{\circ}$ andar, Centro

Porto Alegre - RS - Brasil

$$
\text { CEP } 90035-190
$$

Telefone: +55 (51) 3308-4084

Fax: +55 (51) 3308-4054

www.seer.ufrgs.br/ambienteconstruido

E-mail: ambienteconstruido@ufrgs.br

This is an open-access article distributed under the terms of the Creative Commons Attribution License.

224 Silva, D. M. G. da; Cappellesso, V. G.; Garcia, M. G. L.; Masuero, A. B.; Dal Molin, D. C. C. 